DOI: https://doi.org/10.32838/2523-4803/70-1-5

удК 676

\title{
Колотило П.В.
}

магістр,

Державний університет інфраструктури та технологій

Харчук О.Г.

кандидат економічних наук,

доцент кафедри менеджменту, публічного управління

та адміністрування,

Державний університет інфраструктури та технологій

\section{Kolotylo Pavlo, Kharchuk Olena}

State University of Infrastructure and Technologies

\section{ЦЕЛЮЛОЗНО-ПАПЕРОВА ГАЛУЗЬ У КОНТЕКСТІ ІННОВАЦИЙНОГО РОЗВИТКУ І ВИРОБНИЦТВА ПРОДУКЦЇ̈ В УКРАЇНІ ТА ЗА КОРДОНОМ}

\begin{abstract}
У статті визначено актуальність досліджень тенденцій інноваційного розвитку та виробництва продукції целюлозно-паперової галузі України, розглянуто останні дослідження і публікаиї у иій сфері діяльності та визначено основні етапи виробництва паперу та картону. Розкрито види енергетичних ресурсів та обсяги споживання електричної й теплової енергії, які використовуються підприємствами челюлозно-паперової промисловості України в технологічному прочесі за 2013-2016 рр. Розглянуто зарубіжний досвід новацій у цій сфері діяльності та показники виробництва і споживання иелюлозно-паперової продукиії в Україні за 2014-2018 рр. Визначено основні причини обмеження росту виробництва в паперово-целюлозній промисловості, головні виробники та найбільщі постачальники ресурсного забезпечення галузі. Розглянуто обсяги споживання картонно-паперової продукиії на душу населення та світові експортери паперу. Визначено частку у виробництві иелюлозно-паперової продукиії регіонів світу та розглянуто заходи з підвищення енергоефективності підприсмств целюлозно-паперової галузі.
\end{abstract}

Ключові слова: иелюлозно-паперова галузь, виробництво, інновації, продукиія, Украӥна, краӥни світу.

Постановка проблеми. Дослідження тенденцій інноваційного розвитку та виробництва продукції целюлозно-паперової галузі України $є$ актуальним питанням сьогодення, оскільки в Україні функціонує понад 2,6 тис підприємств із близько 40 тис працівників, що виробляють понад 300 найменувань товарної продукції, яка постачається на внутрішній і зовнішній ринки. А це дає можливість Україні забезпечити населення робочими місцями та підтримувати конкурентні позиції на світовому паперовому ринку.

Близько 100 підприємств галузі здійснюють виробництво і переробку паперу й картону. Щорічно галузь забезпечує випуск товарів більше ніж на 5,5 млрд грн, при цьому $50 \%$ його припадає на 42 потужні підприємства, що розташовані у Львівській, Київській, Чернігівській, Житомирській, Дніпропетровській, Одеській, Хмельницькій областях [17]. Подальший розвиток галузі може позитивно вплинути на розвиток економіки держави та поліпшити взаємозв'язки 3 іншими країнами світу.

Аналіз останніх досліджень і публікацій. Інноваційним розвитком та проблемами функціонування целюлозно-паперової галузі України займалися такі науковці, як А.В. Огієнко [3], О.В. Вінниченко [4], І.Г. Курочкіна [5], В.А. Барбаш [6], Д.В. Зінченко [2], Г.М. Швороб [1] та ін. Однак проблеми впровадження інновацій у розвиток та виробництво даної галузі залишаються до кінця не визначеними та потребують подальшого вивчення з використанням та впровадженням зарубіжного досвіду.

Формулювання цілей статті. Метою статті $\epsilon$ проведення порівняльного аналізу інноваційного розвитку та виробництва продукції целюлозно-паперової галузі України з іншими країнами світу.

Виклад основного матеріалу. Розглянемо більш детально виробництво, ресурси та співвідношення виробництва продукції різних регіонів світу.

Основними етапами виробництва паперу та картону є: отримання целюлози (знімають кору з дерева, подрібнюючи та сортуючи їх на щепки (з різних видів дерев)); виготовлення сульфатної целюлози, нейтрально-сульфатної целюлози - деревної механічної маси та саме виробництво паперу і картону (крім целюлози, також використовуються роздріблені відходи ганчірок та макулатура, які під час взаємодії з хімікатами розчиняються і з великою кількістю води подаються на 
сітку паперо- чи картоноробної машини); відродження стоків та їх біологічне очищення.

У цій сфері діяльності задіяні целюлозні, деревомасні заводи, паперові та картонні фабрики за наявності водних та енергетичних ресурсів. Види енергетичних ресурсів, які використовують целюлозно-паперові підприємства в технологічному процесі, приведено в табл. 1.

Обсяги споживання електричної та теплової енергії підприємствами целюлозно-паперової промисловості України за 2013-2016 рр. показано в табл. 2.

У целюлозно-паперовій промисловості виокремлюють такі типи підприємств, як:

- целюлозно-паперові та картонні комбінати (далі - ЦПК), у яких целюлозні та деревомасні заводи

Таблиця 1

Види енергетичних ресурсів, які використовують целюлозно-паперові підприсмства в технологічному процесі

\begin{tabular}{|c|c|}
\hline $\begin{array}{c}\text { Група технологічних } \\
\text { процесів }\end{array}$ & Енергетичний ресурс \\
\hline \multirow{2}{*}{$\begin{array}{l}\text { Підготовка деревини для } \\
\text { отриманням целюлози } \\
\text { (подрібнення деревини, } \\
\text { iї сортування та ін.) }\end{array}$} & Електрична енергія \\
\hline & Пар \\
\hline \multirow{2}{*}{$\begin{array}{l}\text { Виробництво сульфатної } \\
\text { целюлози }\end{array}$} & Електрична енергія \\
\hline & Пар і гаряча вода \\
\hline \multirow{2}{*}{$\begin{array}{l}\text { Виробництво нейтрально- } \\
\text { сульфатної целюлози }\end{array}$} & Електрична енергія \\
\hline & Пар і гаряча вода \\
\hline \multirow{2}{*}{$\begin{array}{l}\text { Виробництво деревної } \\
\text { механічної маси }\end{array}$} & Електрична енергія \\
\hline & Пар \\
\hline \multirow[t]{2}{*}{ Виробництво паперу і картону } & Електрична енергія \\
\hline & Пар \\
\hline \multirow[t]{3}{*}{ Регенерація хімікатів } & Природний газ \\
\hline & Електроенергія \\
\hline & Пар \\
\hline $\begin{array}{l}\text { Забезпечення роботи } \\
\text { енерготехнологічної ТЕЦ }\end{array}$ & Природний газ \\
\hline Біологічне очищення стоків & Електроенергія \\
\hline
\end{tabular}

Джерело: сформовано авторами згідно з даними [7] поєднуються 3 картонно-паперовими фабриками, що перероблюють напівфабрикати власного виробництва;

- картонні та паперові заводи, що оброблюють целюлозу, яка висушується і привозиться 3 інших целюлозних заводів;

- підприємства, що перероблюють папір і виготовляють вироби із сировини, що доставляється.

Сьогодні галузь цікавить науковців не тільки як виробнича сфера, нею зацікавились як інноваційною наукою у сфері автоматизації виробництва, оптимізації витрат, зменшення собівартості готового продукту та збільшення обсягів виробництва.

Нині целюлозно-паперова галузь не є тільки виробничою, крок за кроком вона все більше пов'язується 3 наукоємною працею, що спричинено автоматизацією виробництва, здешевленням продукції та зростанням обсягів виробництва.

Наприклад, компанія Intentia у м. Стокгольм запустила завод із виробництва порівняного за міцністю 3 кевларом матеріалу, що виготовляється 3 волокон деревини. Дослідження компанії на цьому не закінчуються, і вона впроваджує нові матеріали з іншими властивостями, такі як вологостійкість, твердість, або має змогу змінювати форму і колір, як в «інтерактивному папері» [9].

В Україні також проводять деякі розробки в целюлозно-паперовій промисловості. Більшість із них спрямована на вирішення сировинної проблеми. Зокрема, у КПІ розробили технологію переробки соломи в папір, існують також напрацювання 3 вирощування і переробки технічних рослин. Це є перспективним напрямом, адже щорічно тільки соломи від злакових культур залишається близько 20-30 млн т [6]. Для втілення в життя таких розробок потрібні нові виробничі потужності, хоча вирішення проблеми комплексної заготівлі макулатури могло б значно поліпшити сировинну забезпеченість існуючих підприємств, адже на разі це джерело використовується лише на 20\% [2]. Виробництво та споживання целюлозно-паперової продукції в Україні за 2014-2018 рр. наведено в табл. 3.

Таблиця 2

Обсяги споживання електричної та теплової енергії підприсмствами целюлозно-паперової промисловості України, 2013-2016 рр.

\begin{tabular}{|l|c|c|c|c|c|c|c|}
\hline \multicolumn{1}{|c|}{ Енергетичний ресурс } & \multirow{2}{*}{ Од. вим. } & $\mathbf{2 0 1 3}$ & $\mathbf{2 0 1 4}$ & $\mathbf{2 0 1 5}$ & \multirow{2}{*}{$\mathbf{2 0 1 6}$} & \multicolumn{2}{|c|}{$\begin{array}{c}\text { Відхлення 2016 р. } \\
\text { до 2013 }\end{array}$} \\
\cline { 4 - 8 } & & & & & & Абсол. & \% \\
\hline Електрична енергія, всього, у т. ч.: & тис. кВт/ год. & 783968 & 805278 & 801469 & 838282 & 54314 & 6,5 \\
\hline - на виробництво продукції & тис. кВт/ год. & 748965 & 769854 & 765874 & 775559 & 26594 & 3,4 \\
\hline $\begin{array}{l}\text { - на власні потреби енергогенеруючих } \\
\text { установок }\end{array}$ & тис. кВт/ год. & 31758 & 31958 & 32048 & 32429 & 671 & 2,1 \\
\hline - втрати енергії в мережах енергосистем & тис. кВт/ год. & 3245 & 3466 & 3547 & 3639 & 394 & 10,8 \\
\hline Теплова енергія, у т. ч.: & тис. Гкал & 1175,6 & 1197,3 & 1203,7 & 1232,6 & 57 & 4,6 \\
\hline - на виробництво продукції & тис. Гкал & 1085,6 & 1095,3 & 1100,5 & 1166,7 & 81,1 & 7,0 \\
\hline $\begin{array}{l}\text { - на власні потреби енергогенеруючих } \\
\text { установок }\end{array}$ & тис. Гкал & 47,6 & 46,8 & 47,5 & 48,5 & 0,9 & 1,9 \\
\hline - втрати енергії в мережах енергосистем & тис. Гкал & 2,9 & 3,0 & 3,0 & 3,3 & 0,4 & 12,1 \\
\hline
\end{tabular}

Джерело: сформовано авторами згідно з даними [8] 
Виробництво та споживання целюлозно-паперової продукції в Україні за 2014-2018 рр.

\begin{tabular}{|l|c|c|c|c|c|}
\hline & $\mathbf{2 0 1 4}$ & $\mathbf{2 0 1 5}$ & $\mathbf{2 0 1 6}$ & $\mathbf{2 0 1 7}$ & $\mathbf{2 0 1 8}$ \\
\hline Виробництво, тис т & 945,6 & 927,3 & 1010,3 & 1009,6 & 1011,7 \\
\hline Споживання, тис т & 1537,3 & 1345,1 & 1560,4 & 1559,9 & 1590,3 \\
\hline
\end{tabular}

Джерело: складено авторами згідно з даними [11]

Із табл. 3 видно, що обсяги виробництва і споживання продукції поступово зростають.

У 2014 р. відбувався спад показників, але до 2018 р. виробництво досягло 1011,7 тис т, а споживання - до 1590,3 тис т [12].

Однією 3 основних причин обмеження росту виробництва в паперово-целюлозній промисловості $є$ застарілість засобів виробництва, що проявляється в експлуатації обладнання по 20-30 і більше років. На підприємствах рідко проводиться капітальний ремонт чи модернізація, не говорячи вже про встановлення нових станків та механізмів; зазвичай усе обмежується відновлювальним ремонтом та заміною зношених деталей, що разом із проблемою ресурсного забезпечення сприяє імпортозалежності та обмеженості виробництва на тих видах продукції, що виготовляється із вторинної сировини, тобто $з$ макулатури. Це, зокрема, картон для виробництва тари, коробок, санітарно-гігієнічний та гофрувальний папір. В експорті картонно-промислової продукції також переважають ці види товарів [6].

Розвиток целюлозно-паперової промисловості в країні залежить від споживання іiї продукції, виміряється у визначених показниках. Зокрема, рівень споживання паперу і картону на одну людину в Україні на 50-60\% нижчий від середньосвітових 65 кг/рік, тоді як в Україні він становить 28,2 кг/рік.

Розвинуті країни, зокрема США, Японія, Канада, країни Західної Європи, мають показник, який перевищує 200 кг/рік. Найбільш розвинуті у цьому показнику такі країни Європи, як Бельгія, Фінляндія, Швеція, Данія, Великобританія, які мають показники споживання 334,4 кг/рік, 268 кг/рік, 233,8 кг/рік, 208,8 кг/рік відповідно (рис. 1) [13].

Підтримка целюлозно-паперової галузі державою може забезпечити ії стабільний розвиток, що виража-

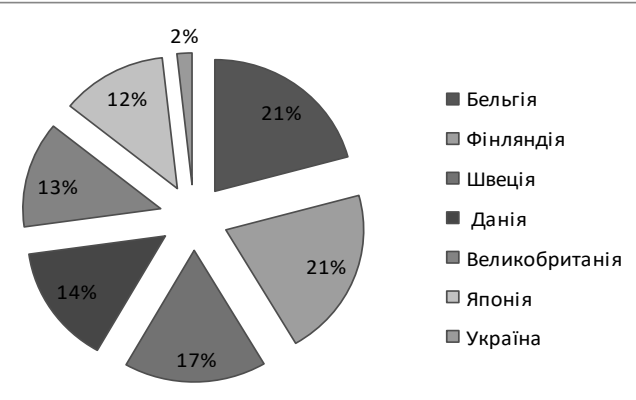

Рис. 1. Обсяги споживання картонно-паперової продукції на душу населення, кг/рік

Джерело: складено авторами згідно з даними [13] ється у вищих показниках виробництва і споживання паперової та картонної продукції. Це опосередковано впливає на показники економічного розвитку населення, екологічної безпеки та соціальної захищеності [14].

Вслід за попитом підвищується й світове виробництво у цій сфері.

Головні виробники - США, Японія, Канада, Швеція, Росія, Фінляндія. Експортують найбільше такі країни, як Канада, Фінляндія, Швеція, Австрія, Норвегія. Імпортують - США, Японія та країни Свропи [15].

Паперово-целюлозне виробництво країн, що розвиваються, характеризується використанням альтернативних джерел сировини 3 недеревних рослин, таких як стебла цукрової тростини, бамбуку, соломи та ін. Це пояснюється обмеженістю ресурсного забезпечення деревиною та вартістю целюлозно-паперових виробів.

Головні виробники - США, Канада, Японія, Росія, Німеччина, Фінляндія, Швеція, Франція, Велика Британія. Найбільші постачальники-Німеччина, Китай, США, Канада, Швеція (рис. 2). Німеччина - \$22,3 млрд (12,7\% від загального експорту паперу), Китай - \$19,5 млрд $(11,1 \%)$, Сполучені Штати - \$16,4 млрд $(9,3 \%)$, Фінляндія - \$9 млрд (5,1\%), Швеція - \$9 млрд $(5,1 \%)$, Канада - \$8 млрд (4,5\%), Італія - \$7,7 млрд (4,4\%), Франція - \$6,9 млрд (3,9\%), Нідерланди - \$5,8 млрд (3,3\%), Австрія - \$5,2 млрд (3\%), Польща - \$5,2 млрд (3\%), Бельгія - \$4,6 млрд (2,6\%), Індонезія - \$4,5 млрд $(2,6 \%)$, Іспанія - \$4,4 млрд (2,5\%), Південна Корея - \$3,3 млрд $(1,9 \%)[11]$.

Якщо розглядати целюлозно-паперову галузь по регіонах, то найбільші виробники - Північна Америка (39,1\%), Азія (25,5\%), Західна Свропа (24,6\%), Латинська Америка (5,1\%) (рис. 3).

Довгострокові споживачі деревини переглядаються для інвестицій у розроблення сировинної основи для целюлозно-паперової промисловості.

Вирішення цих проблем потребує таких кроків:

- першочерговий розвиток деревообробної галузі 3 особливою увагою на галузь цільового паперу як найперспективнішого напряму лісогосподарського комплексу;

- розроблення й утілення в життя плану з будівництва нового целюлозного заводу, що зможе переробляти як деревину, так і альтернативні джерела, зокрема недеревинні види рослин, а також фабрики з виробництва паперу для друку. Це забезпечить як збільшення виробництва паперу та картону, так і якісну переробку вторинної сировини.

Важливим залишається інноваційний розвиток галузі, оскільки дає змогу вітчизняним підприємствам збільшити ефективність роботи та посилити конкурентоспроможність на світовому ринку. У 2018 р. обсяг 


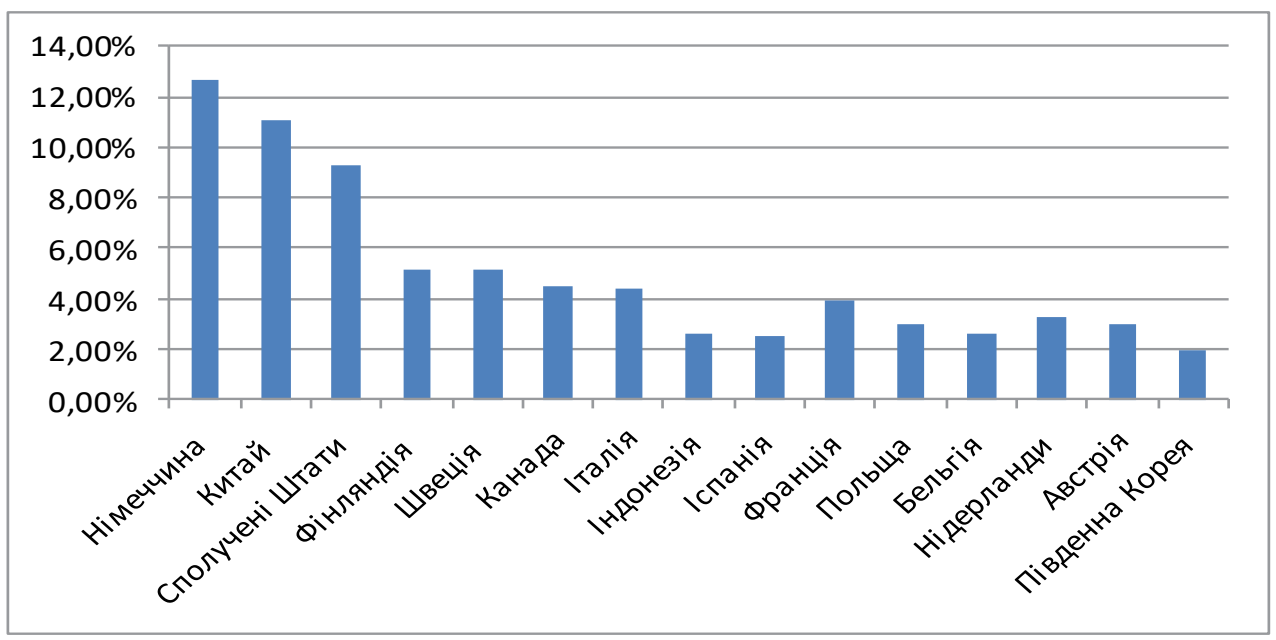

Рис. 2. Світові експортери паперу

Джерело: складено авторами згідно з даними [11]

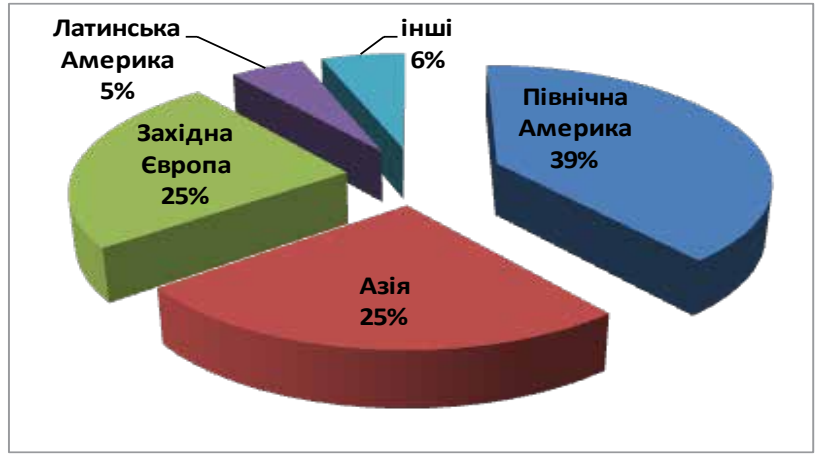

Рис. 3. Частка у виробництві целюлозно-паперової продукції регіонів світу, \%

Джерело: складено авторами згідно з даними [7]

нових замовлень на виробництво паперу та паперових виробів становив 21271,1 млн грн, з яких 40,6\% (8 646,5 млн грн) становлять іноземні замовлення [11].

За цими показниками галузь займає сьоме місце після таких галузей, як металургія (345 890,9 млн грн), виробництво машин та устаткування (44 083,4 млн грн), інших транспортних засобів (36 459,2 млн грн), хімічних речовин та хімічної продукції (33 817,6 млн грн), готових металевих виробів (31 636,3 млн грн) та електричного устаткування (26 507,9 млн грн).

Іншим інноваційним розвитком даної галузі $\epsilon$ використання природних ресурсів, які в Україні не використовуються в повному обсязі, наприклад переробка соломи.

3 урахуванням особливостей розвитку макросередовища і сучасних проблем галузі напрями підвищення енергоефективності підприємств целюлознопаперової промисловості доцільно згрупувати у три основні групи: техніко-технологічні, управлінські та фінансові (рис. 4).

Техніко-технологічні заходи спрямовані на зниження енергоємності устаткування, обладнання, технологічних процесів. Оскільки основні засоби підприємств даної галузі дуже застарілі (60-80\% зносу), вони потребують енергетичної модернізації виробничого та енергетичного устаткування.

Управлінські заходи спрямовані на формування ефективної системи енергетичного менеджменту картонно-паперових комбінатів та заводів, де одним із перспективних напрямів підвищення енергоефективності галузі є стимулювання розвитку спеціалізованого енергетичного консалтингу щодо надання послуг з енергетичного аудиту, сертифікації систем енергетичного менеджменту, енергетичного сервісу.

В Україні $є$ можливість розширити сировинний запас для збільшення асортименту картонно-паперової продукції, яка буде цікавою для інвесторів, що в подальшому підвищить конкурентоспроможність вітчизняних підприємств. Це, наприклад, волоконні напівфабрикати для виробництва картонно-паперової продукції, де переважно використовуються однорічні рослини (наприклад, солома), види паперу для друку, перфорований папір для формулярів, офісний папір для розмножувальної техніки, мішковий папір тощо [10].

Згідно з Концепцією загальнодержавної цільової програми розвитку целюлозно-паперової промисловості України та вітчизняного ринку картонно-паперової продукції [16], перспективними напрямами подальшого розвитку є:

- можливості залучення інвестицій у дану галузь;

- розширення сировинної бази для збільшення асортименту продукції з новими властивостями;

- удосконалення та модернізація виробництва для отримання нового продукту;

- пошук та реалізація нових джерел енергії та оптимізація рівня енергоємності виробництва;

- використання в системі технічного регулювання міжнародних стандартів якості продукції за відповідності її екологічним вимогам;

- посилення техніки безпеки під час ведення технологічного процесу виробництва продукції та охорони праці для іiї виконавців тощо. 


\begin{tabular}{|c|c|c|}
\hline \multicolumn{3}{|c|}{ Заходи з підвищення енергоефективності підприємств целюлозно-паперової галузі } \\
\hline Техніко-технологічні: & & \\
\hline $\begin{array}{l}\text { 1.Модернізація енергетичного } \\
\text { й виробничого устаткування } \\
\text { 2. Оптимізація енергетичних } \\
\text { ресурсів } \\
\text { 3. Зниження рівня втрат у } \\
\text { мережах енергосистем } \\
\text { 4. Збільшення частки } \\
\text { використання вторинних } \\
\text { енергетичних ресурсів } \\
\text { 5. Будівництво та } \\
\text { експлуатація власних } \\
\text { когенераційних установок для } \\
\text { виробництва електричної і } \\
\text { теплової енергії } \\
\text { 6. Використання альтернатив- } \\
\text { них енергетичних ресурсів } \\
\text { 7. Застосування оптимального } \\
\text { розподілу енергетичних } \\
\text { навантажень }\end{array}$ & $\begin{array}{l}\text { 1.Проведення попереднього } \\
\text { енергетичного аудиту } \\
\text { господарської діяльності } \\
\text { підприємства } \\
\text { 2. Впровадження } \\
\text { організаційної структури } \\
\text { системи енергетичного } \\
\text { менеджменту } \\
\text { 3. Відповідність системи } \\
\text { менеджменту ДСТУ ISO } 5001 \\
\text { «Системи енергетичного } \\
\text { менеджменту» } \\
\text { 4. Мотивація та } \\
\text { стимулювання працівників } \\
\text { до економічного } \\
\text { використання енергетичних } \\
\text { ресурсів }\end{array}$ & \begin{tabular}{l}
\multicolumn{1}{|c|}{ Фінансові: } \\
1. Фінансування \\
на впровадження \\
інновацій у \\
діяльність \\
вітчизняних \\
підприємств \\
2. Інвестиції у \\
розроблення \\
сировини \\
3. Активна \\
підтримка з боку \\
держави
\end{tabular} \\
\hline
\end{tabular}

\section{Рис. 4. Заходи з підвищення енергоефективності підприємств целюлозно-паперової галузі \\ Джерело: складено авторами згідно з даними [10]}

Висновки. Отже, проведені дослідження визначили тенденції розвитку целюлозно-паперової галузі України, етапи виробничого процесу продукції, чинники впливу на конкурентоспроможність продукції на світовому ринку, та розроблено напрями посилення енергоефективності підприємств даної галузі. Головними завданнями подальшого розвитку галузі є:
- посилення експортної діяльності галузі (виготовлення продукції, що користується на світовому ринку великим попитом);

- модернізація виробництва шляхом упровадження smart-технологій;

- формування ефективної системи техніко-технологічного, фінансового та енергетичного менеджменту целюлозно-паперової галузі.

\section{Список літератури:}

1. Швороб Г.М. Проблеми і перспективи розвитку целюлозно-паперової промисловості України. Вісник ХНТУ. 2010. № 1. С. 48.

2. Зінченко Д.В., Дунська Д.Р. Проблеми та перспективи розвитку целюлозно-паперової промисловості України в умовах світового ринку. Актуальні проблеми економіки та управління. 2014. Вип. 8. URL : http://probl-economy.kpi.ua/ ru/node/398 (дата звернення: 27.10.2019).

3. Огієнко А.В. Аналіз стану та напрями удосконалення зовнішньої торгівлі України. Культура народів Причорномор'я. 2011. № 208. С. 186-189.

4. Вінниченко О.В. Аналіз та структуризація причин, що перешкоджають упровадженню прогресивних технологій біржової торгівлі зерном. Проблеми економіки. 2015. № 3. С. 32-38. URL : http://nbuv.gov.ua/UJRN/Pekon_2015_3_5 (дата звернення: 05.11.2019).

5. Курочкіна І.Г. Аналіз тенденцій розвитку світової торгівлі товарами та послугами. Бізнес Інформ. 2015. № 9. C. 37-42. URL : http://nbuv.gov.ua/UJRN/binf 201597 (дата звернення: 14.11.2019).

6. Барбаш В.А. Потенціал недеревної рослинної сировини для виробництва паперу і картону. Лісове господарство, лісова, паперова і деревообробна промисловість. 2011. № 1(37). С. 171-180.

7. Технічна енциклопедія Tеch Trend. Виробництво - целюлоза. URL : http://techtrend.com.ua/index. php?newsid=23195 (дата звернення: 19.20.2019).

8. Статистичний збірник «Постачання та використання енергії за 2016 рік». Київ, 2017. URL : http://ukrstat.gov.ua (дата звернення: 20.11.2019).

9. Innventia. URL : http://innventia.com/en/Projects/Innovations1 (дата звернення: 21.11.2019).

10. Офіційний сайт Асоціації «Укрпапір». URL : http://ukrpapir.org/news.php (дата звернення: 23.11.2019). 
11. Державна служба статистики України. URL : www.ukrstat.gov.ua (дата звернення: 23.11.2019).

12. Гончар І.А., Бабірад-Лазунін В.О. Характер формування зовнішньої торгівлі України: статистична оцінка. Статистика України. 2015. № 2. С. 16-20.

13. Міжнародна економіка та міжнародні економічні відносини : практикум / В.В. Козик та ін. ; 2-е вид., перероб. і доп. Київ : Вікар, 2006. 589 с.

14. Клочко В.П. Зовнішньоторговельні відносини України в умовах посилення інтеграційних зв'язків. Актуальні проблеми економіки. 2011. № 11. С. 141-155.

15. The observatory of economic complexity. URL : http://atlas.media.mit.edu/ru (дата звернення: 24.11.2019).

16. Концепція загальнодержавної цільової програми розвитку целюлозно-паперової промисловості України та вітчизняного ринку картонно-паперової продукції на період до 2020 року. URL : http://www.ligazakon.ua/summary_ news/news/2009/9/3/16637.htm (дата звернення: 24.11.2019).

17. Болгар Т.М., Сгоров А.С. Проблеми функціонування торговельного та целюлозно-паперового сектору економіки України. Ефективна економіка. 2018. № 1. URL : http://www.economy.nayka.com.ua/?op=1\&z=6046 (дата звернення: 25.11.2019).

\section{References:}

1. Shvorob G. M. (2010) Problemy i perspektyvy rozvytku tselyulozno-paperovoyi promyslovosti Ukrayiny [Problems and prospects of development of pulp and paper industry of Ukraine]. Bulletin of the KhNTU, no. 1, p. 48. [in Ukrainian].

2. Zinchenko D. V., Duns'ka D. R. (2014) Problemy ta perspektyvy rozvytku tselyulozno-paperovoyi promyslovosti Ukrayiny u sviti [Problems and prospects of development of pulp and paper industry of Ukraine in the world]. Topical Issues in Economics and Management, vol. 8. Available at: http://probl-economy.kpi.ua/ru/node/398 (accessed 27 October 2019). [in Ukrainian].

3. Ogienko A. V. (2011) Analiz stanu ta napryamy udoskonalennya zovnishn'oyi torhivli Ukrayiny [Analysis of the state and directions of improvement of foreign trade of Ukraine]. Culture of the Black Sea peoples, no. 208, pp. 186-189. [in Ukrainian].

4. Vinnichenko O. V. (2015) Analiz ta strukturyzatsiya prychyn, shcho pereshkodzhayut' uprovadzhennyu prohresyvnykh tekhnolohiy birzhovoyi torhivli zernom [Analysis and structuring of the reasons that impede the implementation of progressive technologies of grain trading]. Problems of economy, no. 3, pp. 32-38. Available at: http://nbuv.gov.ua/UJRN/ Pekon_2015_3 5 (accessed 05 November 2019). [in Ukrainian].

5. Kurochkina I. G. (2015) Analiz tendentsiy rozvytku svitovoyi torhivli tovaramy ta posluhamy [Analysis of trends in world trade in goods and services]. Business Inform, no. 9, pp. 37-42. Available at: http://nbuv.gov.ua/UJRN/binf_2015_9_7 (accessed 14 November 2019). [in Ukrainian].

6. Barbash V. A. (2011) Potentsial nederevnoyi roslynnoyi syrovyny dlya vyrobnytstva paperu i kartonu [Potential of non-timber vegetable raw materials for paper and cardboard production]. Forestry, forestry, paper and wood industry, 2011. no. 1 (37), pp. 171-180. [in Ukrainian].

7. Tekhníchna yentsiklopedíya Tech Trend. Virobnitstvo - tselyuloza[Technical Encyclopedia Tech Trend. Virobnitstvo cellulose ]. Available at: http://techtrend.com.ua/index.php?newsid=23195 (accessed 19 November 2019).

8. Statystychnyy zbirnyk «Postachannya ta vykorystannya enerhiyi za 2016 rik». Kyyiv, 2017. [Statistical collection «Energy supply and use for 2016»]. Available at: http://ukrstat.gov.ua (accessed 20 November 2019). [in Ukrainian].

9. Invenventia. [Invenventia]. Available at: http://innventia.com/en/Projects/Innovations1 (accessed 21 November 2019). [in Ukrainian].

10. Ofitsiynyy sayt Asotsiatsiyi «Ukrpapir».[Official site of the Association «Ukrpapir»]. Available at: http://ukrpapir.org/ news.php (accessed 23 November 2013). [in Ukrainian].

11. Derzhavna sluzhba statystyky Ukrayiny.[State Statistics Service of Ukraine.] Available at: www.ukrstat.gov.ua (accessed 23 November 2019). [in Ukrainian].

12. Gonchar I. A., Babirad-Lazunin V. A. (2015) Kharakter formuvannya zovnishn'oyi torhivli Ukrayiny: statystychna otsinka. [Character of Foreign Trade Formation of Ukraine: Statistical Assessment]. Statistics of Ukraine, no. 2, pp. 16-20. [in Ukrainian].

13. Kozik V. V., Pankova L. A., Grigoryev A. Y., Bosak A. O. [International Economics and International Economic Relations]: (2nd ed., Rev.). Kyiv: Vicar, 589 p. [in Ukrainian]. [in Ukrainian].

14. Klochko V. P. (2011) Zovnishn'otorhovel'ni vidnosyny Ukrayiny v umovakh posylennya intehratsiynykh zv'yazkiv [Foreign trade relations of Ukraine under conditions of strengthening integration ties]. Current problems of the economy, 2011. no. 11, pp. 141-155. [in Ukrainian].

15. The observatory of economic complexity. Available at: http://atlas.media.mit.edu/ru (accessed 24 November 2019). [in Ukrainian].

16. Kontseptsiya zahal'noderzhavnoyi tsil'ovoyi prohramy rozvytku tselyulozno-paperovoyi promyslovosti Ukrayiny ta vitchyznyanoho rynku kartonno-paperovoyi produktsiyi na period do 2020 roku.[ The concept of a nationwide targeted program for the development of the pulp and paper industry of Ukraine and the domestic market for cardboard and paper products for the period up to 2020.] Available at: http://www.ligazakon.ua/summary_news/news/2009/9/3/16637.htm (accessed 24 November 2013). [in Ukrainian].

17. Bolgar T. M, Egorov A. E. (2018) Problemy funktsionuvannya torhovel'noho ta tselyulozno-paperovoho sektoru ekonomiky Ukrayiny [Problems of functioning of trade and pulp and paper sector of economy of Ukraine]. An efficient economy, no 1. Available at: http://www.economy.nayka.com.ua/?op=1\&z=6046 (accessed 25 November 2019). [in Ukrainian]. 


\section{ЦЕЛЛЮЛОЗНО-БУМАЖНАЯ ПРОМЫШЛЕННОСТЬ В КОНТЕКСТЕ ИННОВАЦИОННОГО РАЗВИТИЯ И ПРОИЗВОДСТВА ПРОДУКЦИИ В УКРАИНЕ И ЗА РУБЕЖОМ}

В статье определена актуальность исследований тенденций инновационного развития и производства продукиии целлюлозно-бумажной отрасли Украины, рассмотрены последние исследования и публикации в данной сфере деятельности и определены основные этапы производства бумаги и картона. Раскрыты виды энергетических ресурсов и объемы потребления электрической и тепловой энергии, используемой предприятиями иеллюлозно-бумажной промышленности Украины в технологическом проиессе, за 2013-2016 г2. Рассмотрен зарубежный опыт новаций в этой сфере деятельности и показатели производства и потребления иеллюлознобумажной продукиии в Украине за 2014-2018 г2. Определены основные причины ограничения роста производства в бумажсно-целлюлозной промышленности, главные производители и крупнейшие поставщики ресурсного обеспечения отрасли. Рассмотрены объемы потребления картонно-бумажной продукиии на душу населения и мировые экспортеры бумаги. Определена доля в производстве иеллюлозно-бумажной продукции регионов мира и рассмотрены пути повышения энергоэффективности предприятий целлюлозно-бумажной отрасли.

Ключевые слова: ијеллюлозно-бумажная отрасль, производство, инновации, продукция, Украина, страны мира.

\section{THE PULP AND PAPER INDUSTRY IN THE CONTEXT OF INNOVATIVE DEVELOPMENT AND PRODUCTION IN UKRAINE AND ABROAD}

The article determines the relevance of research into the trends of innovative development and production of products of the pulp and paper industry of Ukraine, reviews recent research and publications in this field, namely the work of such scientists as AV Ogienko, OV Vinnichenko, IG Kurochkina, V.A. Barbash, D.V. Zinchenko, G.M. Shvorob and others. The main stages of paper and cardboard production, types of energy resources, volumes of electricity and heat consumption by the enterprises of the pulp and paper industry of Ukraine for 2013-2016 and the types of enterprises of the pulp and paper industry are considered. Foreign experience of production with use of raw materials with new properties is considered. The volume of production and consumption of pulp and paper products in Ukraine for 2014-2018 is revealed and the reasons for limiting the growth of production are identified. The main producers of products are the USA, Canada, Japan, Russia, Germany, Finland, Sweden, France, Great Britain. The largest suppliers are Germany, China, USA, Canada, Sweden. The share of pulp and paper production in the regions of the world was determined in percentages with the largest producers being North America (39.1\%), Asia (25.5\%), Western Europe (24.6\%) and Latin America (5.1\%). In 2018, new orders for the production of paper and paper products amounted to 21,271.1 million UAH, of which 40.6\% (8646.5 million UAH) are foreign orders. According to these indicators, the industry ranks seventh after such industries as metallurgy - UAH 345890.9 million, production of machinery and equipment - UAH 44083.4 million, other vehicles UAH 36459.2 million, chemicals and chemical products - 33817.6 million UAH, finished metal products - 31636.3 million UAH. and electrical equipment - UAH 26507.9 million. Innovative directions of development of pulp and paper industry in Ukraine and measures of energy efficiency improvement of its enterprises are identified. Prospective directions for further development of the industry under the Concept of a nationwide targeted program for the development of the pulp and paper industry of Ukraine and the domestic market of cardboard and paper products are revealed. Ukraine will be able to expand its raw stock to increase the range of cardboard and paper products that will be of interest to investors, which will further increase the competitiveness of domestic enterprises.

Key words: pulp and paper industry, production, innovation, products, Ukraine, countries of the world. 